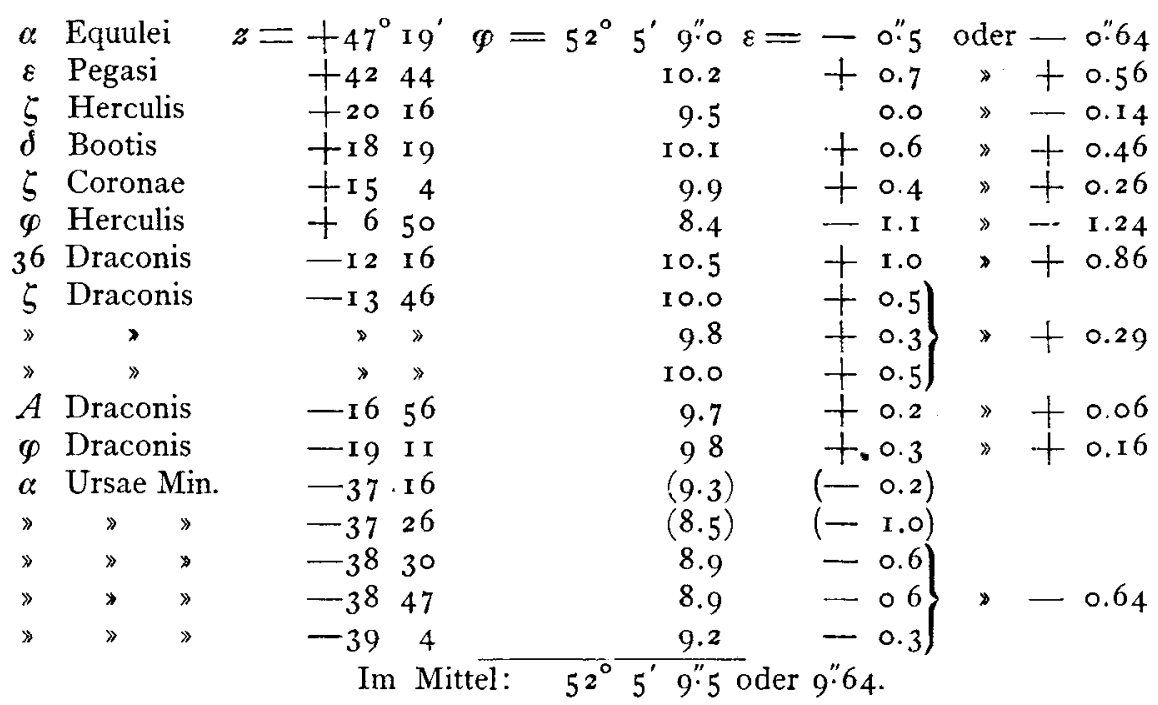

Bei der Bestimmung des Biegungscoefficienten sind den arithmetischen Mitteln zwischen den drei Beobachtungen resp. von $\zeta$ Draconis und $\alpha$ Ursae minoris gleiches Gewicht wie den anderen Bestimmungen zuerkannt. Bei dieser Rechenweise wird die Polhöhe $52^{\circ} 5^{\prime} 9^{\prime \prime} 64$. Die beiden eingeklammerten durch den Polarstern erhaltenen Resultate sind von Herrn Marine-Lieutenant Tadema, und datiren vom Jahre 1878 ; sie stimmen aber sehr gut mit jenen von Herrn Blaaur. Werden diese auch mitgerechnet und die durch denselben Stern erhaltenen getrennt gehalten, so ist das allgemeine Mittel $52^{\circ} 5^{\prime} 9^{\prime \prime} 5$. Sämmtliche Resultate sind Mittel aus 6 oder 8 in abwechselnder Lage ausgeführten Circummeridianbeobachtungen, nur der Polarstern wurde an beliebigen Stellen seines Parallels beobachtet.

Schroeder van der Kolk fand im J. 1857 durch Beobachtungen im ersten Vertical $52^{\circ} 5^{\prime}$ I O." $_{5}$; (A. N. I $28 \mathrm{I}$ ). Von seinen drei Reihen stimmt die dritte aber nicht besonders mit den. beiden ersten (I. Reihe 10". I9; 2. Reihe го."I ; 3. Reihe го" 84). Sein Standpunkt war um o"I9 nördlicher als der Ort des Universal-Instruments. Es bleibt also zwischen der damaligen und der jetzigen Bestimmung noch eine Differenz von 0.8 resp. o.66 übrig, welche wahrscheinlich grösstentheils den Sternörtern zuzuschreiben ist. Leider würde es eine sehr unsichere Sache sein, die Oerter der von Schroeder van der Kolk benutzten Sterne für I 857 auf den Catalog der 539 Sterne zu reduciren, um sein Resultat darnach zu verbessern; und wird es also besser sein, zur Vergleichung der beiden Methoden eine neue Bestimmung im ersten Vertical auszuführen.

Das gebrauchte Universal-Instrument hat einen verticalen Kreis von $260 \mathrm{~mm}$. Durchmesser, (einen horizontalen von $328 \mathrm{~mm}$.), die Oeffnung des Objectivs ist $67 \mathrm{~mm}$., die Vergrösserung war 68. Mit demselben Instrumente habe ich auf dem hiesigen "Dom « eine Azimuthbestimmung von Amersfoort ausgeführt. Von dieser Arbeit wird bald ein Rapport: $\left.{ }^{*}\right)$ nebst Zeichnungen des Instruments erscheinen.

Utrecht I88I November 24 . F. A.C. Oudemans.
$K r$.

\title{
Schreiben des Herrn John Tebbutt an den Herausgeber.
}

I have read the letter of Dr. Gould dated June $\mathrm{I} 6$ last in Nr. 2384 of the "Astronomische Nachrichten " with much interest. It is quite obvious from the small change in the relative declinations of the comet and the bright star of comparison that the latter could not be a fixed star and the only feasible conclusion is that it was a companion comet. But that this object had no existence a short time previously to Dr. Gould's observation is, I think, shown by negative evidence in the following verbatim extract from my Observatory Journal. The entry is dated Monday, June 13: "The horizon being clear before sunrise yesterday morning, the $\mathrm{I} 2^{\text {th }}$, civil time, I rose to observe the comet. The diffused twilight and the full moon in the opposite part of the sky, however, prevented my seeing any stars near the comet for comparison. There was certainly no star of the 7. mag. or upwards sufficiently near to it. I was, therefore, obliged to make circle comparisons with the bright star Rigel. « Here follow the details of the observations. The method adopted was to observe the transits of Rigel and the comet over the transit thread, while each in its turn was kept bisected by the fixed declination wire, the polar axis being firmly clamped for each comparison. The differences of RA. were inferred from the transits and those of declination from the readings of the declination circle. Four comparisons were made, but in the last the transit time for the comet was not observed, but only the time of bisection. The Windsor mean times of the comet's transit in the first comparison and of its bisection in the fourth were respectively $18^{\mathrm{b}} 22^{\mathrm{m}} 54^{\mathrm{s}} .2$ and $18 \mathrm{~b} 38^{\mathrm{m}} 29^{\mathrm{s}} \mathrm{o}$. On reducing the latter to the meridian of Cordoba it will be found that the observation preceded the first comparison at Cordoba by only $\mathrm{I}^{\mathrm{h}} \mathbf{2}^{\mathrm{m}}$ of absolute 
time. I feel confident that at my last observation no such object as that described by Dr. Gould could have been in the field with the comet. $\mathbf{A}$ fifth comparison was attempted, but failed owing to the faintness of the comet in the increasing twilight. The following evening was too cloudy for observation, but I succeeded in getting an imperfect comparison on the evening of the $13^{\text {th }}$.

Should the above remarks be deemed of sufficient importance to appear in the Astronomische Nachrichten « they are at your service.

Observatory Windsor, N. S. Wales, I 88 I Oct. Io.
Postscript. Can Dr. Gould by any possibility have observed the blurred images of the stars BAC. I 592, I 597 ? And if so, is the former a variable? It is somewhat significant that the difference of position of these two stars agrees almost exactly with that of his objects, and, moreover, different magnitudes have been asssigned to BAC. 1592 by different observers. Lalande at one time estimated it of the $6^{\text {th }}$ magnitude and at another of the $7^{\text {th }}$. Schjellerup gives 6 as the magnitude. It is now too late to examine this star for my present cormunication as the mail closos to-morrow at Sydney.

Fohn Tebbutt.

Bemerkung. Der Unterschied der beiden Sterne BAC. I 592 und I $597=\lambda$ Eridani entspricht in der That sehr genau der Gould'schen Beobachtung. Nach Stone's Catalog von I 244 I Sternen ist die Position dieser Sterne, I $881.0: 5^{\mathrm{h}} 2^{\mathrm{m}} 3^{8 \mathrm{~s} .2 \mathrm{I}}-8^{\circ} 49^{\prime}{ }^{\prime} 5^{\prime \prime} \cdot 4$ und $5^{\mathrm{h}} 3^{\mathrm{m}} 27^{\mathrm{s}} .05-8^{\circ} 54^{\prime} 28^{\prime \prime} 6$; die daraus folgende Differenz $\Delta \alpha=+48^{\mathrm{s}} .84, \Delta \delta=-5^{\prime}$ I $3^{\prime \prime} \cdot 2$ (nach einer Mittheilung in »Observatory « Nr. 57 hat Herr Tebbutt hierfür später beobachtet: +48.99 und - 5' $3^{\prime \prime} \cdot \mathrm{I}$ ) kommt sehr nahe auf die von Dr. Gould beobachtete hinaus, welche nach Anbringung der Refraction +49.I 1 und - $5^{\prime} \times 0^{\prime \prime} 5$ geben. würde, wenn man sie mit der bei Gould angegebenen Sternzeit und Position berechnet. Wird indessen der Ort von $\lambda$ Eridani für den Cometen eingesetzt, so rückt die Beobachtung dem Horizont noch viel näher und die Refractionscorrection wird grösser, die relative Bewegung aber null. Darnach muss ich auch glauben, dass Gould's Messungen sich auf diese beiden Sterne beziehen und dass zwischen der ersten richtigen Einstellung des Cometen und der folgenden Micrometermessung eine grobe Verstellung des Fernrohrs Statt gefunden hat, wodurch der Comet, bei der grossen Annäherung an den Horizont, mit dem hellen Sterne $\lambda$ Eridani verwechselt werden konnte. Der Sterrn BAC. I 592 ist von Prof. Schönfeld als $6^{\mathrm{m}} .8$ beobachtet worden, von Gould, Uranometria Argentina als $6^{\mathrm{m}} \cdot 5$; in Stone's Catalog ist die Grösse $2 u 5^{\mathrm{m}}$ angegeben: ich glaube nicht, dass das vorhandene Material bereits Anlass giebt, ihn für veränderlich zu halten.

$K r$.

\section{Transit of Mercury 1881 November 7-8.}

The meteorological conditions were very favourable here for the observation of this important phenomenon. The contacts were observed with the full aperture of the $4 \frac{1}{2}$ inch equatorial furnished with Cooke's diagonal prism and a negative eyepiece of 120 diameters. The field lens was smoked and a shade of a brownish green colour was fitted on between the eye and eye-lens. By this combination the sun's limb was of a straw colour and the sky dark. The steadiness and definition of the objects were such as to admit of very accurate determinations of the contacts. Unfortunately, however, I was some seconds late in catching the first external contact, the notch in the solar limb being very marked when first seen. The three other contacts were exceedingly well observed. There was no black drop, no shadowy ligament like that observed at the transit of Venus in 1874 , nor was I troubled with the triangular black ligament seen by me at the egress of Mercury in May 1878 . The following are the observed phases in local mean time:

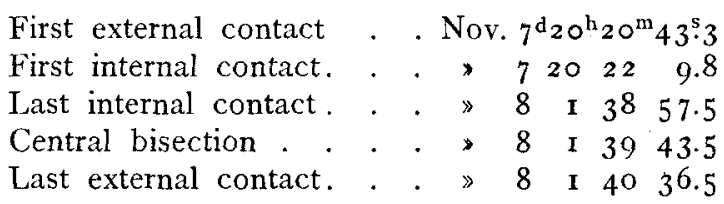

I believe the contacts as above given were as nearly geometrical as can possibly be observed. The geometrical contact is a theoretical rather than a practical matter. The formation or the rupture of the line of light between the limbs can hardly be an instantaneous phenomenon. In the present case this line, notwithstanding the steadiness and good definition, brightened up or faded so gradually that it was impossible to determine within two or three half seconds of the chronometer what was the precise instant of its formation or disappearance. At the ingress two or three rapid undulations of light occurred between the closing cusps and the thread of light was at once established. Six and a half seconds later, or at $20^{\mathrm{h}} 22^{\mathrm{m}} 16^{\mathrm{s}} \cdot 3$ the band of light had become very distinct. At ${ }^{\mathrm{b}}{ }^{\mathrm{b}} 8^{\mathrm{m}} 54^{\mathrm{s}} \cdot 5$ the line of light at egress was very fine; three seconds later it was broken and the contact was certainly complete. Every precaution was taken to secure correct mean time. Grood transit observations were obtained on the evenings preceding and following the phenomenon, and a transit of Regulus was also observed shortly before the ingress. Notwithstanding a careful examination the planet could not be seen either before or after its projection on the sun, owing probably to filmy clouds which overspread the sky. There was no halo round the planet, nor was there any trace of a satellite. A faint whitish spot was, however, occasionally seen on the planet's disc, and the disc itself was not always perfectly black. At times it seemed to reflect a very faint grayish light. The sunspot phenomena on the day of the transit were exceedingly interesting.

Observatory Windsor i 88 I Nov. I4.

Fohn Tebbutt. 